\title{
Penapisan Tiga Puluh Tujuh Genotipe Tomat dan Seleksi Primer RAPD untuk Toleransi terhadap Layu Bakteri (Ralstonia solanacearum)
}

\author{
Screening of Thirty Seven Tomatoes Genotypes and RAPD Primer Selection \\ for Ralstonia solanacearum Tolerance \\ Eriana Adeputri ${ }^{1}$, Rustikawati2 ${ }^{*}$, Dotti Suryati ${ }^{2}$ dan Catur Herison ${ }^{2}$ \\ ${ }^{1}$ Dinas Pertanian Provinsi Bengkulu. \\ ${ }^{2}$ Program Studi Agroekoteknologi Fakultas Pertanian Universitas Bengkulu \\ *: rustikawati@unib.ac.id
}

\begin{abstract}
Bacterial wilt (Ralstonia solanacearum) is the most important tomato diseases which can reduce tomato yield up to $100 \%$. One most prospective control measure is the development of high yielding varieties tolerance to bacterial wilt. Donor parent carrying bacterial wilt controlling gene(s) is required to develop such varieties. The objectives of this study were to screen thirty-seven tomato genotypes for tolerance to $R$. solanacearum and to obtain RAPD markers of resistance to bacterial wilt. The experiment was arranged without the experimental design. Each tomato genotypes consisting of 5 control uninoculated plants and 10 plants were inoculated with $R$. solanacearum with a concentration of $106 \mathrm{cfu} / \mathrm{ml}$ inoculum of $10 \mathrm{~mL}$ per plant. Scoring was done on the severity of disease symptom; and the plants were grouped according to scoring class. Molecular analysis was done by using Bulk Segregant Analysis (BSA). The results showed there were six genotypes considerd very tolerant i.e. genotype Pearl, Opal, Cung, Syu and Kudamati I; tolerant genotypes consisting of five genotypes; medium tolerant groups consisting of eight genotypes; medium sensitives groups consisting of 14 genotypes; and sensitive class consisting of four genotypes, namely Aceh Local Tomatoes I, Tanah Datar Local Tomato, Tomato Meranti I and Tomato Meranti II. Of the 20 primers used only 8 primers showed visible DNA bands, they were E1, E7, E10, H2, H5, H13, H16 and H19. However there no polymorphics bands observed for bacterial wilt tolerance.
\end{abstract}

Key word: BSA, genotipe tomat, layu bakteri, penapisan, RAPD

\begin{abstract}
ABSTRAK
Penyakit layu bakteri (Ralstonia solanacearum) dapat menurunkan produktivitas tanaman tomat hingga 100\%. Salah satu solusi yang dapat dilakukan adalah dengan merakit varietas unggul toleran layu bakteri. Untuk itu, diperlukan jenis tomat toleran layu bakteri. Hal tersebut dapat diperoleh dengan cara penapisan tanaman koleksi dan analisis molekuler gen penanda sifat ketahanan terhadap layu bakteri. Penelitian ini bertujuan menyeleksi tiga puluh tujuh genotipe tomat untuk toleransi terhadap $R$. solanacearum dan mendapatkan primer RAPD penanda ketahanan terhadap layu bakteri. Percobaan disusun tanpa rancangan percobaan. Masing-masing genotipe tomat terdiri dari 15 tanaman yaitu 5 tanaman kontrol dan 10 tanaman yang diinokulasi $R$. solanacearum dengan konsentrasi $10^{6} \mathrm{cfu} / \mathrm{mL}$ sebanyak $10 \mathrm{~mL}$ inokulum per tanaman. Skoring tanaman dilakukan menurut Winstead dan Kelman (1952). Berdasarkan data skoring tanaman dikelompokkan sesuai kelasnya dengan metode Tiwari dkk (2012). Analisis molekuler dilakukan
\end{abstract}


dengan teknik Bulk Segregant Analysis (BSA). Hasil penelitian menunjukkan terdapat lima kelas toleransi yaitu kelas Sangat Toleran yang terdiri dari 6 genotipe yaitu tomat Mutiara, Opal, Cung, Syu dan Tomat Lokal Kudamati I, kelas Toleran terdiri dari 5 genotipe, kelas Agak Toleran terdiri dari 8 genotipe, kelas Agak Peka terdiri dari 14 genotipe dan kelas Peka terdiri dari 4 genotipe yaitu Tomat Lokal Aceh I, Tomat Lokal Tanah Datar, Tomat Meranti I dan Tomat Meranti II. Dari 20 primer yang digunakan hanya 8 primer yang terlihat pita DNAnya yaitu $\mathrm{E}_{1}, \mathrm{E}_{7}, \mathrm{E}_{10}, \mathrm{H}_{2}, \mathrm{H}_{5}, \mathrm{H}_{13}, \mathrm{H}_{16}$ dan $\mathrm{H}_{19}$ namun tidak ditemukan yang polimorfik.

Kata kunci: BSA, genotipe tomat, layu bakteri, penapisan, RAPD

\section{PENDAHULUAN}

Tomat (Lycopersicon esculentum Mill.) merupakan komoditi sayuran yang cukup penting selain cabai, bawang dan kentang. Tomat kaya akan likopen yang berfungsi sebagai antioksidan serta vitamin A dan C untuk mencegah sariawan dan rabun (Siagian, 2005). Selain dikonsumsi segar, tomat juga diolah menjadi berbagai macam produk seperti saus, jus dan manisan sehingga permintaannya selalu meningkat. Pada tahun 2011 produksi tomat dalam negeri mencapai 954064 ton namun masih dilakukan impor tomat sebanyak 10 639 ton (BPS, 2012). Tingkat produktivitas tomat yang belum optimal disebabkan berbagai faktor, diantaranya rendahnya potensi genetik varietas yang dibudidayakan dan tingginya serangan penyakit terutama pada musim hujan. Untuk hasil tomat diperlukan varietas unggul yang sesuai lokasi penanaman, teknik budidaya yang tepat, pemupukan berimbang serta pengendalian hama dan penyakit yang efektif (Purwati, 2008).

Salah satu penyakit tanaman yang penting dalam budidaya tomat adalah layu bakteri yang disebabkan oleh Ralstonia solanacearum. Bakteri tersebut menyebabkan layu pada tanaman tomat yang mampu bertahan di tanah hingga bertahun-tahun dan menyebar bersama-sama dengan run off. Perkembangbiakan $R$. solanacearum yang optimal adalah pada suhu berkisar $24^{\circ} \mathrm{C}-35^{\circ} \mathrm{C}$ (Stansburry et al., 2001). Penu- runan hasil tomat akibat serangan $R$. solanacearum bisa mencapai 5-100 \%. Dengan potensi kerugian terbesar di daerah dataran rendah (Direktorat Perlindungan Hortikultura, 2012). Pada suhu udara dan suhu tanah yang tinggi gejala layu bakteri terjadi lebih cepat (Mew dan Ho, 1977).

Tanaman yang terinfeksi $R$. solanacearum mengalami penyumbatan pembuluh pengangkut, sehingga tanaman membentuk akar samping pada batang bagian bawah yang mengakibatkan tanaman kerdil dan mengalami klorosis (Hartman dan Elphinstone, 1994). Pada daerah dengan suhu harian tinggi, gejala serangan akan lebih cepat terlihat seperti daun termuda layu berlanjut ke bagian lain tanaman, jika batang dipotong maka akan terlihat warna kecoklatan dan keluar lendir yang merupakan massa bakteri (European and Mediteranian Plant Production Organization, 2004).

Produktivitas tanaman yang relatif rendah dan serangan layu bakteri adalah persoalan utama yang menyebabkan rendahnya produksi tomat nasional. Pendekatan yang dapat dilakukan adalah melalui program pemuliaan guna merakit varietas yang memiliki potensi hasil tinggi sekaligus toleran terhadap layu bakteri. Untuk merakit varietas yang demikian diperlukan plasma nutfah dengan sumber gen hasil tinggi dan toleran layu bakteri. Tomattomat lokal yang dikoleksi dari berbagai provinsi di Indonesia diduga memiliki potensi kedua sifat tersebut akibat adaptasi pada lingkungan masing-masing. Untuk 
menentukan keragaman jenis tomat koleksi tersebut perlu dilakukan karakterisasi. Karakterisasi secara molekuler sangat akurat karena tidak dipengaruhi oleh lingkungan dan fase pertumbuhan tanaman.

Salah satu teknologi untuk mengidentifikasi molekuler tanaman yang umum dilakukan adalah Random Amplified Polymorphic DNA (RAPD) (Waldron et al., 2002). Marka molekuler yang dihasilkan dapat mendeteksi keragaman tanaman pada tingkat DNA genom. Penanda RAPD dihasilkan melalui proses amplifikasi DNA menggunakan primer oligonukleotida (dengan panjang 10 basa) yang sekuennya dibuat secara acak. Genom hampir setiap organisme tersusun dari jutaan nukleotida, yang secara teoritis akan banyak yang sekuen DNAnya sama dengan sekuen dari random oligonukleotida primer. Jika genom tersebut dipakai sebagai templat untuk reaksi PCR, maka DNA genom yang sekuennya sama dengan sekuen random oligonukleotida primer yang orientasinya berlawanan arah (inverted orientation) dan yang hanya berjarak beberapa ratus atau ribu pasang basa antara satu dengan yang lain akan teramplifikasi. Berbagai ukuran potongan DNA hasil amplifikasi akan dapat dengan mudah dipisahkan berdasarkan ukurannya dengan menggunakan teknik elektroforesis dan hasilnya dapat dilihat sebagai pita-pita DNA dengan berbagai ukuran (Williams et al., 1990). Penggunaan RAPD mampu menghasilkan potonganpotongan DNA hasil pelipatgandaan yang masing-masing potongan DNA dapat digunakan sebagai karakter untuk keperluan analisis (Dumeke dan Adam, 1994). Pada tomat, penanda RAPD berhasil diketahui terkait dengan gen pembawa sifat ketahanan terhadap nematoda (Klein-Lankhorst et al., 1991). Penanda RAPD juga terkait dengan gen Fom 2 untuk sifat ketahanan pada fusarium pada muskmelon MR1 (Wechter et al., 1995). Penelitian ini bertujuan un- tuk menyeleksi 37 genotipe tomat untuk toleransi terhadap $R$. solanacearum dan mendapatkan primer RAPD penanda sifat toleran layu bakteri.

\section{METODE PENELITIAN}

Penelitian ini dilaksanakan pada bulan September sampai Desember 2013 di Kelurahan Kandang Limun, Kecamatan Muara Bangkahulu, Kota Bengkulu. Tomat yang diuji sebanyak 37 genotipe yang berasal dari berbagai daerah di Indonesia. Tiap genotipe tomat ditanam 15 tanaman. Sepuluh tanaman diinokulasi bakteri $R$. solanacearum dan lima tanaman sebagai kontrol.

Inokulum $R$. solanacearum yang digunakan pada penelitian ini merupakan isolat yang diperoleh dari Kecamatan Ujan Mas, Kabupaten Rejang Lebong, Provinsi Bengkulu yang telah dimurnikan di Laboratorium Ilmu Hama dan Penyakit Tanaman Fakultas Pertanian Universitas Bengkulu. Isolat bakteri ini selanjutnya disuspensikan dalam $1 \mathrm{~L}$ air sebagai inokulum dengan kepekatan $10^{6} \mathrm{cfu} / \mathrm{mL}$.

Benih tomat disemai pada tray dan dipelihara selama 4 minggu. Bibit dipindahkan ke polibag yang berisi media tanah sebanyak $1 \mathrm{Kg}$. Tiga hari setelah pindah tanam dilakukan inokulasi bakteri $R$. solanacearum dengan cara menyiram cairan inokulum sebanyak $10 \mathrm{~mL}$ per tanaman. Sebelum inokulasi media tanaman ditusuktusuk dengan kayu agar terjadi pelukaan pada bagian akar tanaman. Polibag-polibag ini diletakkan dengan jarak antar polibag $10 \mathrm{~cm}$.

Tanaman dipupuk dengan dosis setara dengan $200 \mathrm{~kg}$ urea ha-1, $200 \mathrm{~kg}$ SP36 $\mathrm{ha}^{-1}$ dan $100 \mathrm{~kg} \mathrm{KCl} \mathrm{ha-1}$. Pengairan dilakukan pagi dan sore hari apabila tidak turun hujan. Pengendalian gulma dilakukan secara manual, sedangkan pengendalian terhadap hama dan jamur dilakukan secara 
kimiawi dengan mengaplikasikan insektisida berbahan aktif Deltamethrin $2.5 \mathrm{~g} / 1$ dan fungisida berbahan aktif Mankozeb 80 $\%$ sebanyak dua kali seminggu.

Penentuan kelas toleransi pada masing-masing genotipe dilakukan pada saat tanaman berumur 5 minggu. Nilai skoring intensitas serangan layu bakteri ditentukan menurut Winstead dan Kelman (1952) yang dicantumkan pada Tabel 1. Dari nilai skoring kemudian ditentukan tingkat toleransi tanaman terhadap $R$ solanacearum mengikuti Tiwari et al (2012) dicantumkan pada Tabel 2.

Seleksi primer dilakukan dengan metode BSA (Bulk Segregant Analysis) yaitu dengan menggabungkan seluruh tanaman yang tergolong dalam satu kelas kriteria toleransi. Bagian tanaman yang digunakan adalah daun pada tanaman kontrol tiap genotipe yang berada pada kelas toleransi yang sama untuk selanjutnya dilakukan isolasi DNA. Isolasi DNA dari tanaman masing-masing kelas toleransi dilakukan mengikuti metode Herison et al. (2012). Pada tahapan ini, random primer yang digunakan sebanyak 60 primer dari operon
OPE, OPH dan OPM.

Metode amplifikasi DNA dengan program PCR adalah satu siklus pre PCR pada suhu $94^{\circ} \mathrm{C}$ selama 5 menit, 45 siklus terdiri atas denaturasi pada suhu $94^{\circ} \mathrm{C}$ selama 5 detik, annealling pada suhu TM-4 selama 30 detik, elongation pada suhu $72^{\circ}$ C selama 1 menit dan satu siklus stop PCR pada suhu $72^{\circ} \mathrm{C}$ selama 10 menit. Visualisasi hasil PCR dilakukan dengan elektroforesis pada gel agarose 0.6 gram menggunakan bufer TAE 1x sebanyak $40 \mathrm{~mL}$, pada voltase konstan sebesar 100 volt selama 60 menit. Staining dilakukan dengan cara merendam gel dalam larutan etidium bromida $(0.5 \mathrm{mg} / \mathrm{l})$ selama 10 detik, kemudian direndam aquades selama 30 menit. Pola pita pada gel selanjutnya didokumentasikan menggunakan Gel Documentation.

Sebagai variabel pendukungnya adalah rata-rata hari inkubasi, jumlah daun, luas daun, tingkat kehijauan daun, kerapatan stomata dan bobot kering brangkasan. Data yang diperoleh disajikan dalam bentuk diagram batang menurut kelas toleransinya.

Tabel 1. Skoring gejala serangan $R$. solanacearum menurut Winstead dan Kelman (1952)

\begin{tabular}{cl}
\hline Intensitas Serangan & \multicolumn{1}{c}{ Gejala } \\
\hline 0 & Tidak ada gejala \\
1 & Satu daun layu \\
2 & Dua atau tiga daun layu \\
3 & Semua daun layu kecuali dua atau tiga daun teratas \\
4 & Semua daun layu \\
5 & Tanaman mati \\
\hline
\end{tabular}

Tabel 2. Kelas toleransi menurut Tiwari et al. (2012)

\begin{tabular}{ll}
\hline Index Penyakit $(\%)$ & Kriteria Toleransi \\
\hline 0 & Sangat Toleran \\
$1-10$ & Toleran \\
$11-25$ & Agak Toleran \\
$26-50$ & Agak Peka \\
$51-75$ & Peka \\
$76-100$ & Sangat Peka \\
\hline
\end{tabular}




\section{HASIL DAN PEMBAHASAN}

\section{Masa Inkubasi masing-masing Genotipe Tomat}

Masa inkubasi dipengaruhi oleh umur tanaman, konsentrasi bakteri, virulensi inokulum dan faktor lingkungan. Semakin lama masa inkubasi bakteri pada klon tertentu maka semakin kecil kemampuan bakteri menginfeksi tanaman tersebut (Sastra, 2013). Semakin muda umur tanaman, lebih mudah diinfeksi $R$. solanacearum atau sebaliknya (Nurhayati dan Serliana, 2011). Hal ini disebabkan karena sel-sel tanaman muda belum memiliki dinding sel yang kuat sehingga bakteri lebih mudah masuk dan cepat menginfeksi tanaman. Semakin tinggi konsentrasi larutan inokulum maka populasi bakteri juga semakin besar sehingga bakteri lebih cepat menyebar dan menimbulkan gejala yang terlihat pada tanaman. Kemampuan bakteri menginfeksi juga berperan penting. Virulensi tanaman dapat diujicoba dengan menguji langsung pada tanaman atau secara in vitro menggunakan media TZC (Tetrazolium Chloride), yaitu media khusus mengisolasi $R$. solanacearum. Tingkat virulensi bakteri ditandai dengan tumbuhnya koloni bakteri berwarna merah (USDA, 2009).

Grafik masa inkubasi yang diperoleh pada penelitian ini menunjukkan bahwa garis standar error pada kelas sangat toleran dan toleran tidak bersinggungan dengan garis standar error pada kelas toleransi lain. Sedangkan kelas toleransi agak toleran, agak peka, dan peka garis-garis standard errornya masih bersinggungan bila ditarik garis lurus. Hal ini menyatakan bahwa pada variabel rata-rata masa inkubasi pada kelas sangat toleran dan kelas toleran berbeda dengan kelas toleran lainnya secara statistik (Gambar 1).

Respon tanaman yang berbeda-beda terhadap infeksi layu bakteri dipengaruhi oleh faktor lingkungan dan genetik. Mew dan Ho (1977) menyebutkan bahwa faktor lingkungan seperti kelembaban serta suhu tanah dan udara, sangat mempengaruhi laju serangan layu bakteri. Pada suhu tanah dan suhu udara yang tinggi, gejala layu bakteri dapat menjadi lebih parah. Kultivar-kultivar yang tahan dapat menjadi peka apabila ditanam di daerah yang memiliki kelembaban dan suhu tinggi. Dengan demikian, genotipe yang tahan terhadap layu bakteri di daerah asalnya belum tentu menunjukkan sifat toleransi yang sama apabila ditanam di daerah lain. Selain faktor lingkungan, genetik juga menentukan ketahanan tanaman tomat. Rostiana et al. (2010) dalam penelitiannya menggunakan gen penyandi sifat tahan terhadap $R$. solanacearum (gen RRS1-R) untuk menginduksi sifat ketahanan tanaman jahe terhadap penyakit layu bakteri.

\section{Toleransi Genotipe Tomat terhadap $R$. solanacearum}

Serangan bakteri $R$. solanacearum pada tanaman tomat umumnya dicirikan dengan gejala layu pada daun (USDA, 2009). Keparahan gejala layu daun dapat digunakan untuk mengidentifikasi kriteria toleransi tomat terhadap layu bakteri. Winstead dan Kelman (1952) mendapatkan teknik skoring untuk mengukur tingkat toleransi tanaman tomat terhadap layu bakteri berdasarkan kondisi daun tanaman tomat. Pada penelitian ini, genotipe-genotipe tomat koleksi yang telah diinveksi inokulum bakteri $R$. solanacearum menunjukkan gejala layu. Hasil skoring dihitung menjadi persen indeks penyakit agar dapat dibagi menjadi kelas-kelas. Berdasarkan hasil pengamatan diketahui terdapat 5 kelas toleransi tomat terhadap layu bakteri yaitu kelas sangat toleran, kelas toleran, kelas agak toleran, kelas agak peka, dan kelas peka. Hasil identifikasi menunjukkan bahwa tidak ada genotipe yang tergolong dalam kelas sangat peka. Hal ini karena tidak 


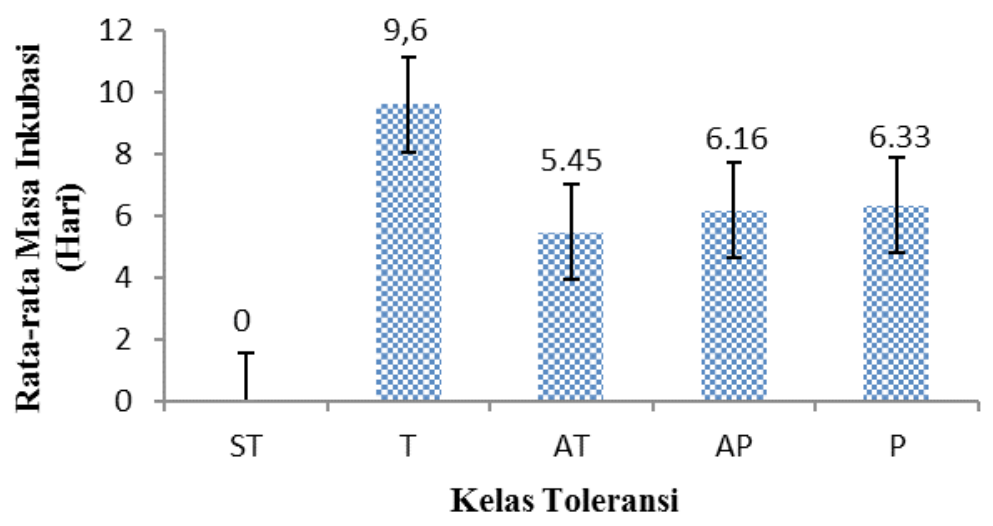

Gambar 1. Rata-rata Masa Inkubasi Tiap Kelas Toleransi

Keterangan $: \mathrm{ST}=$ Sangat Toleran, $\mathrm{T}=$ Toleran, $\mathrm{AT}=$ Agak Toleran, $\mathrm{AP}=$ Agak Peka, $\mathrm{P}=$ Peka .

terdapat genotipe yang mengalami indeks penyakit sebesar $76-100 \%$. Persen indeks penyakit terbesar sebesar $60 \%$ ditunjukkan oleh seluruh genotipe yang terdapat pada kelas peka.

Pada kelas sangat toleran, empat dari enam genotipe adalah genotipe tomat lokal. Keempat genotipe tomat lokal tersebut adalah tomat Cung, Syu, Kudamati I, dan Kefaminano XII (Tabel 3). Data ini menunjukkan bahwa varietas lokal memiliki kelebihan diantaranya ketahanan kethadap layu bakteri karena sudah beradaptasi lama sehingga diduga memiliki gen ketahanan terhadaap layu bakteri. Genotipe Kudamati I dari Ambon dan tomat lokal Kefaminano XIV dari NTT juga menunjukkan sifat sangat toleran meskipun ditanam bukan di daerah aslinya. Sedangkan genotipe Mutiara dan Opal merupakan genotipe asal Balitsa yang memiliki sifat toleran layu bakteri dan adaptif di dataran rendah. Purwati et al. (2001) menyebutkan bahwa genotipe Opal memiliki tingkat toleransi terhadap layu bakteri yang lebih tinggi dibandingkan genotipe Ratna, Intan dan Mirah. Hal ini terbukti, pada kondisi lingkungan yang berbeda, sifat toleran terhadap layu bakteri dapat terpatahkan. Genotipe Ratna tergolong kelas Toleran dan genotipe Intan dan Mirah tergolong agak peka.
Respon tanaman yang berbeda-beda terhadap infeksi layu bakteri dipengaruhi oleh faktor lingkungan dan genetik. Mew dan Ho (1977) menyebutkan bahwa faktor lingkungan seperti kelembaban serta suhu tanah dan udara, sangat mempengaruhi laju serangan layu bakteri. Pada suhu tanah dan suhu udara yang tinggi, gejala layu bakteri dapat menjadi lebih parah. Kultivar-kultivar yang tahan dapat menjadi peka apabila ditanam di daerah yang memiliki kelembaban dan suhu tinggi. Di Australia, tomat Rodade dimanfaatkan sebagai sumber gen toleran layu bakteri (Barnes dan Vawdrey, 1993), namun di Florida tomat Rodade justru menunjukkan sifat peka (Scott et al., 1993). Selain faktor lingkungan, genetik juga sangat menentukan ketahanan tanaman tomat. Rostiana et al. (2010) dalam penelitiannya menggunakan gen penyandi sifat tahan terhadap layu bakteri (gen RRS1-R) untuk menginduksi sifat ketahanan tanaman jahe terhadap penyakit layu bakteri. Monma dan Sakata (1993) melakukan persilangan antara tomat toleran layu bakteri dengan tomat peka layu bakteri untuk mempelajari pewarisan sifat toleran layu bakteri. Dari penelitian ini, genotipe yang tergolong pada kelas sangat toleran berpotensi untuk dijadikan sumber gen toleran layu bakteri $R$. solanacearum. Namun, ge- 
Tabel 3. Kriteria toleransi genotipe tomat berdasarkan persen indeks penyakit

\begin{tabular}{ll}
\hline Kriteria Toleransi & Genotipe \\
\hline Sangat toleran & Mutiara, Opal, Cung, Syu, Kudamati I, Kefaminano XII \\
Toleran & Ratna, Berlian, Lombok I, Lombok II, Ranti Situbondo \\
& Gelombang \\
Agak toleran & CLN 4046, Kudamati II, Makassar I, Makassar II, Kefaminano \\
& VI, Ranti Situbondo Bulat Kecil, Cherry, Kemir \\
Agak peka & Intan, Mirah, Lombok III, Lombok IV, Kefaminano III, \\
& Kefaminano VII, Kefaminano IX, Kefaminano XIV, Aceh III, \\
& Aceh V, Situbondo, Bajawa, Gondol Lonjong, Kali Acai Abepura \\
Peka & Aceh I, Tanah Datar, Meranti I, Meranti II \\
\hline
\end{tabular}

notipe yang tahan terhadap layu bakteri di daerah asalnya belum tentu menunjukkan sifat toleransi yang sama apabila ditanam di daerah lain.

\section{Karakteristik Morfologi pada Tiap Ke- las Toleransi}

Hasil pengamatan pada persen ratarata penurunan jumlah daun menunjukkan bahwa kelas dengan persen penurunan terbesar sebesar $78.76 \%$ yaitu kelas peka dan persen penurunan terkecil yaitu $35.69 \%$ pada kelas toleran (Gambar 2). Pada kelas sangat toleran meskipun tanaman tidak menunjukkan gejala layu tetapi mengalami penurunan pada variabel jumlah daun sebesar $47.12 \%$. Tidak terdapat perbedaan yang nyata antara kelas sangat toleran, toleran, agak toleran dan agak peka. Sedangkan kelas peka satu-satunya kelas yang berbeda dari kelas lainnya secara statistik.

Penurunan jumlah daun terjadi pada tanaman terinfeksi dikarenakan layu bakteri menyebabkan layu pada daun terutama daun teratas sehingga daun layu, menguning, dan lama-kelamaan kering/mati, atau tanaman mengalami kerdil sehingga daun tidak tumbuh sempurna (Martin dan French, 1985). Hal lain yang juga berpotensi menghambat tanaman dalam memproduksi daun adalah karena tanaman membentuk akar adventif untuk menyerap air dan hara ke batang tanpa melalui pembuluh angkut terinfeksi.
Hasil pengamatan ini mendukung adanya sifat rentan pada genotipe-genotipe dalam kelas peka yang menyebabkan penurunan jumlah daun hingga hampir $80 \%$. Di lapangan, tanaman tomat dari kelas ini tetap menumbuhkan daun namun jarak antar daun tidak rapat sehingga jumlah daun berkurang dibandingkan jumlah daun pada tanaman kontrol. Hal ini berlaku pada semua kelas toleransi, termasuk kelas sangat toleran. Dengan demikian, infeksi layu bakteri menurunkan jumlah daun meskipun dari hasil skoring tanaman tergolong sangat toleran.

Zat hijau daun (klorofil) berperan bagi proses fotosintesis. Tingkat kehijauan daun menjadi indikator jumlah klorofil yang dimiliki tanaman dan jumlah atau laju fotosintesis. Tingkat kehijauan daun juga mengindikasikan kesuburan tanaman atau defisiensi terhadap suatu unsur. Semakin banyak klorofil maka semakin banyak cahaya yang diterima daun untuk melakukan fotosintesis (Adhitya et al., 2013).

Pada diagram penurunan tingkat kehijauan tanaman dari kelas sangat toleran dengan persen penurunan terkecil $7.07 \%$ meningkat terus hingga kelas peka dengan persen penurunan sebesar $64.19 \%$ (Gambar 3). Secara statistik hanya kelas peka yang berbeda tingkat penurunan kehijauan daun dibandingkan kelas-kelas lainnya. Hal ini membuktikan bahwa semakin rentan tanaman terhadap layu bakteri maka se- 


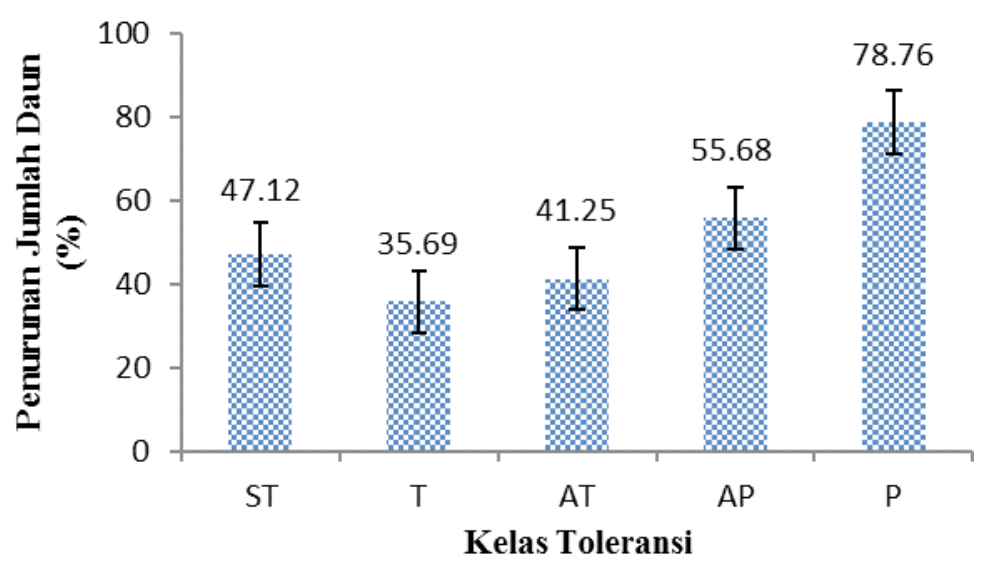

Gambar 2. Rata-rata penurunan jumlah daun tiap kelas toleransi Keterangan $: \mathrm{ST}=$ Sangat Toleran, $\mathrm{T}=$ Toleran, $\mathrm{AT}=$ Agak Toleran, $\mathrm{AP}=$ Agak Peka, $\mathrm{P}=$ Peka .

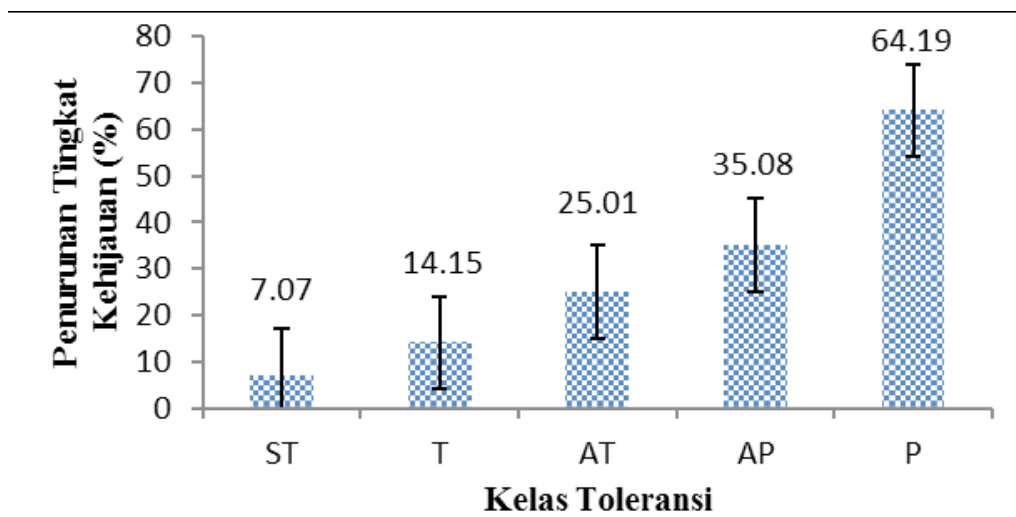

Gambar 3. Rata-rata penurunan kehijauan daun tiap kelas toleransi Keterangan $: \mathrm{ST}=$ Sangat Toleran, $\mathrm{T}=$ Toleran, $\mathrm{AT}=$ Agak Toleran, $\mathrm{AP}=$ Agak Peka, $\mathrm{P}=$ Peka .

makin sedikit pula kandungan klorofilnya. Akibatnya energi cahaya yang diterima untuk melakukan fotosintesis berkurang, laju fotosintesis menurun, metabolisme tanaman terganggu dan tanaman lebih cepat terlihat gejala serangannya. Sehingga, tingkat kehijauan daun dapat digunakan sebagai indikator tingkat kepekaan tanaman terhadap layu bakteri.

Serangan layu bakteri yang menyerang daun sebagai indikator pertama gejala penyakit menyebabkan daun layu dan kerdil sehingga luasan daun berkurang. Luasan daun penting untuk proses fotosintesis dan transpirasi. Hasil penelitian Adhitya et al. (2013) bahwa pemberian naungan hingga $50 \%$ akan meningkatkan luas daun. Peningkatan luas daun terjadi agar tanaman dapat menangkap cahaya matahari secara maksimal untuk melakukan fotosintesis. Hal ini berarti bahwa semakin luas daun maka semakin banyak cahaya matahari yang diterima dan laju fotosintesis semakin tinggi. Demikian halnya dengan proses transpirasi. Pada saat suhu harian tinggi laju transpirasi akan meningkat, namun bakteri menyerang pembuluh angkut menghalangi asupan air dari akar ke daun sehingga daun menjadi layu atau luas daunnya berkurang dibandingkan tanaman kontrol. 
Penurunan luas daun terkecil pada kelas toleransi agak toleran dan penurunan luas daun terbesar pada kelas toleransi peka. Sedangkan kelas sangat toleran mengalami penurunan hingga 50.82\% (Gambar 4). Sedangkan secara statistik, seperti pada variabel kerapatan stomata dan kehijauan daun, kelas peka merupakan satu-satunya kelas yang berbeda. Hal ini mengindikasikan bahwa serangan layu bakteri berdampak pada penurunan luas daun termasuk terhadap tanaman sangat toleran dan terutama pada tanaman peka. Penurunan luas daun dapat dijadikan indikator serangan layu bakteri secara umum.

Suhu harian dan intensitas penyinaran yang tinggi dapat memicu peningkatan suhu tanaman. Suhu tinggi tersebut dapat merusak protein dan mengganggu metabolisme tanaman. Transpirasi dilakukan sebagai salah satu mekanisme tanaman terhadap suhu tinggi. Transpirasi terjadi di stomata pada daun dan lentisel pada batang. Dengan demikian, stomata berperan penting bagi kelangsungan hidup tanaman. Kerapatan stomata merupakan perbandingan jumlah stomata pada suatu luasan bidang pandang tertentu. Jumlah stomata berbanding lurus dengan laju transpirasi pada daun. Semakin banyak stomata juga dapat menyebabkan semakin sedikit bahan kering pada tanaman. Jumlah stomata dipengaruhi oleh genetik tanaman.

Indikator infeksi $R$. solanacearum secara visual salah satunya adalah gejala layu pada daun. Kerapatan stomata ratarata pada tanaman terinfeksi di semua kelas lebih tinggi dibandingkan dengan kerapatan stomata tanaman kontrol. Bahkan kelas toleran mencapai angka $87.43 \%$ lebih rendah dibanding tanaman yang terinfeksi (Gambar 5), sedangkan kelas sangat toleran menempati angka penurunan terkecil dari kelas toleransi lainnya yaitu $-28.41 \%$. Secara statistik hanya kelas toleran berbeda dengan kelas lain. Hal ini diduga terjadi karena adanya penurunan luas daun. Serangan layu bakteri menyebabkan penyempitan luas daun sehingga jumlah stomata menjadi lebih rapat pada satu bidang pandang dan jumlahnya terlihat lebih banyak.

Bobot brangkasan kering merupakan penampilan jumlah bahan kering/non air yang dapat diserap dari dalam tanah atau dihasilkan tanaman selama hidup dan berfotosintesis menjadi jaringan tanaman. Pengukuran bobot brangkasan kering juga digunakan untuk mengetahui kadar air tanaman. Pada variabel kerapatan stomata disebutkan bahwa semakin banyak jumlah stomata maka semakin sedikit bahan kering yang terdapat pada tanaman.

Kandungan bahan kering pada tanaman dipengaruhi oleh kerapatan stomata. Sumenda et al. (2011) menyatakan bahwa semakin banyak stomata menyebabkan semakin sedikit bahan kering pada tanaman. Hal ini terbukti pada pengamatan kerapatan stomata dan bobot kering brangkasan, kelas yang menunjukkan respon penurunan tertinggi adalah kelas toleran. Sedangkan kelas sangat toleran mengalami penurunan sebesar $39.36 \%$ dan kelas peka hanya sebesar $22.81 \%$ (Gambar 6). Secara statistik penurunan bobot brangkasan pada kelas sangat toleran tidak berbeda dengan kelas toleran, begitu pula kelas peka, agak peka, dan agak toleran tergolong seragam. Dengan demikian dari beberapa variabel di atas infeksi layu bakteri dapat menurunkan jumlah daun, luas daun dan bobot brangkasan kering pada kelas sangat toleran namun tidak menunjukkan penurunan yang mencolok pada variabel kehijauan daun.

\section{Seleksi primer RAPD untuk toleransi terhadap layu bakteri}

Dari operon E, $\mathrm{H}$ dan $\mathrm{M}$ terdapat 10 primer yang dapat mengamplifikasi DNA tomat. Ke sepuluh primer tersebut yaitu $\mathrm{E}_{1}, \mathrm{E}_{7}, \mathrm{E}_{10}, \mathrm{H}_{2}, \mathrm{H}_{5}, \mathrm{H}_{13}, \mathrm{H}_{16}, \mathrm{H}_{19}$, dan $\mathrm{M}_{1}$ (Tabel 4) Dari 20 primer pada operon E, 


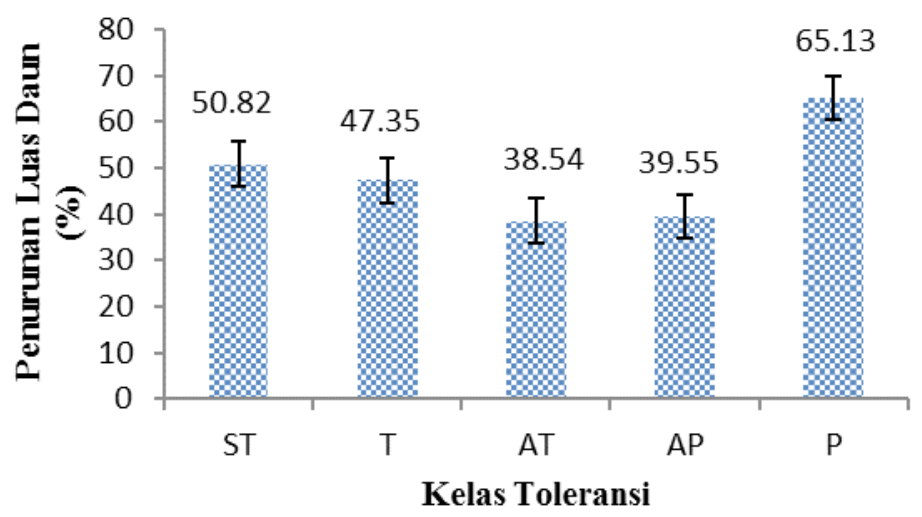

Gambar 4. Rata-rata penurunan luas daun tiap kelas toleransi

Keterangan : $\mathrm{ST}=$ Sangat Toleran, $\mathrm{T}=$ Toleran, $\mathrm{AT}=$ Agak Toleran, $\mathrm{AP}=$ Agak Peka, $\mathrm{P}=$ Peka .

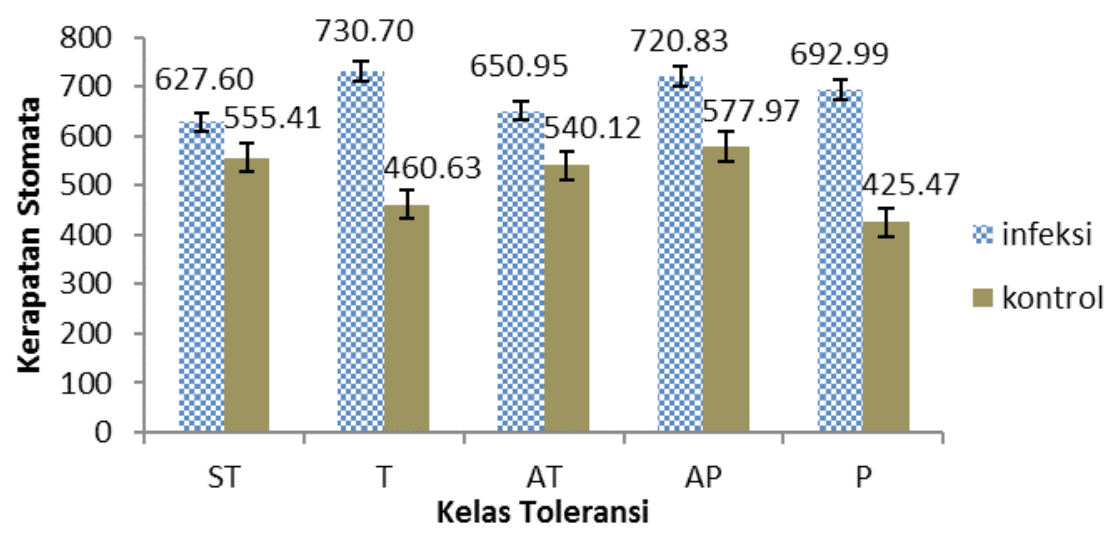

Gambar 5. Kerapatan stomata pada tanaman terinfeksi layu bakteri dan tanaman kontrol tiap kelas toleransi

Keterangan $: \mathrm{ST}=$ Sangat Toleran, $\mathrm{T}=$ Toleran, $\mathrm{AT}=$ Agak Toleran, $\mathrm{AP}=$ Agak Peka, $\mathrm{P}=$ Peka.

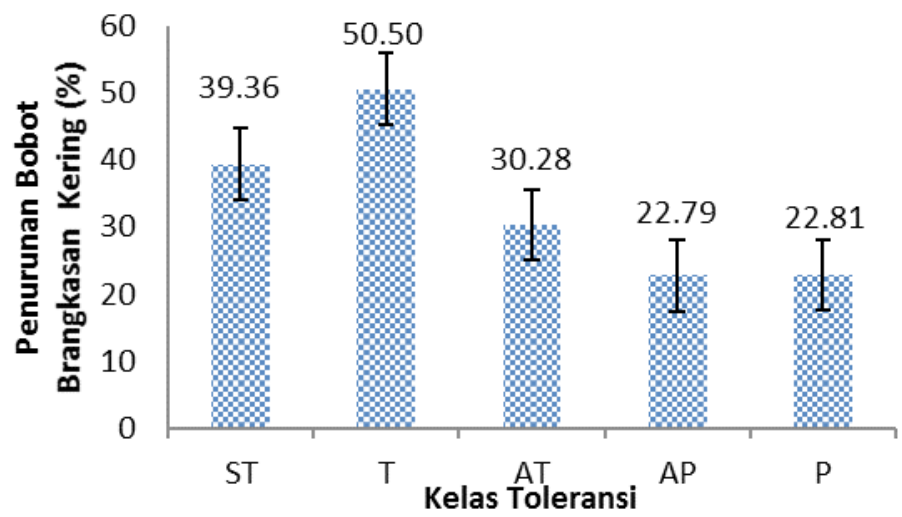

Gambar 6. Rata-rata penurunan bobot brangkasan kering tiap kelas toleransi Keterangan : $\mathrm{ST}=$ Sangat Toleran, $\mathrm{T}=$ Toleran, $\mathrm{AT}=$ Agak Toleran, $\mathrm{AP}=$ Agak Peka, $\mathrm{P}=$ Peka . 
empat primer yang mengamplifikasi bulk DNA sangat toleran yaitu $\mathrm{E}_{1}, \mathrm{E}_{7}, \mathrm{E}_{10}$, dan $\mathrm{E}_{19}$ berturut-turut menghasilkan 11, 10, 14, dan 9 pita DNA. Sedangkan pada operon $\mathrm{H}$, primer $\mathrm{H}_{2}, \mathrm{H}_{5}, \mathrm{H}_{13}, \mathrm{H}_{16}$, dan $\mathrm{H}_{19}$ masingmasing menghasilkan $8,4,8,10$, dan 8 pita DNA. Primer $\mathrm{M}_{18}$ menghasilkan 8 pita DNA (Tabel 5). Total jumlah pita DNA adalah 90 pita DNA, namun belum diperoleh polimorfisme dengan bulk sangat toleran. Sedangkan terhadap bulk peka pita DNA yang muncul lebih banyak. Primer $\mathrm{E}_{1}, \mathrm{E}_{7}$, $\mathrm{E}_{10}$, dan $\mathrm{E}_{19}$ masing-masing menghasilkan 11, 23, 14, dan 9 pita DNA. Pada primer $\mathrm{H}_{2}, \mathrm{H}_{5}, \mathrm{H}_{13}, \mathrm{H}_{16}$, dan $\mathrm{H}_{19}$ berturut-turut muncul 9, 7, 8, 10, dan 8 pita DNA. Primer $\mathrm{M}_{18}$ menghasilkan 8 pita DNA sehingga total 109 pita DNA pada bulk peka. Hal ini berarti primer $\mathrm{E}_{7}, \mathrm{H}_{2}$, dan $\mathrm{H}_{5}$ memunculkan pita DNA yang polimorfis terhadap bulk peka.

Rostiana et al. (2010) menyatakan bahwa bisa saja tidak terjadi amplifikasi karena sifat DNA yang spesifik. Primer hanya akan menempel pada bagian DNA single strand yang cocok urutan basanya. DNA yang ditempeli primer akan menjadi DNA template dan berlipat jumlahnya sesuai banyak siklus yang dilakukan (amplifikasi). Hasilnya diperoleh copy DNA yang sama

Tabel 4. Urutan Basa pada Random Primer OPE, OPH dan OPM

\begin{tabular}{lll}
\hline No & Operon & Urutan Basa \\
\hline 1 & OPE-1 & CCCAAGGTCC \\
2 & OPE-7 & AGATGCAGCC \\
3 & OPE-10 & CACCAGGTGA \\
4 & OPE-19 & ACGGCGTATG \\
5 & OPH-2 & TCGGACGTGA \\
6 & OPH-5 & AGTCGTCCCC \\
7 & OPH-13 & GACGCCACAC \\
8 & OPH-16 & TCTCAGCTGG \\
9 & OPH-19 & CTGACCAGCC \\
10 & OPM-18 & CACCATCCGT \\
\hline
\end{tabular}

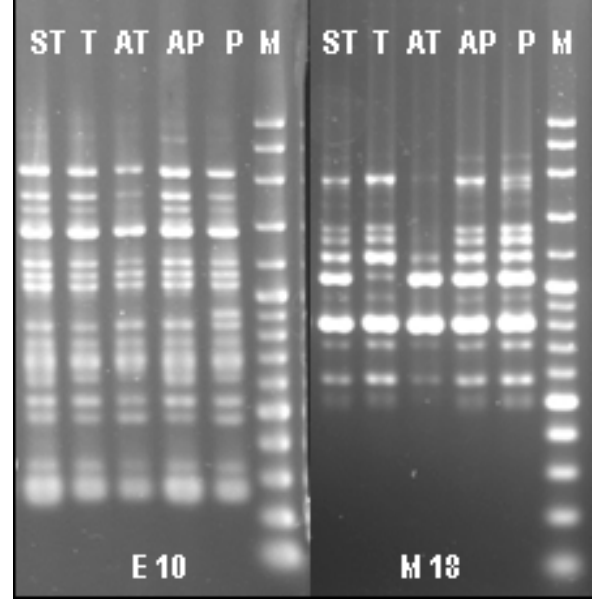

Gambar 7. Visualisasi penanda RAPD dengan primer E10 dan M18 menggunakan template bulk DNA sangat tahan (ST), toleran (T), agak tahan (AT), agak peka (AP), peka (P) dan marker (M) 
Tabel 5. Daftar hasil amplifikasi Bulk DNA sangat toleran dan Bulk DNA peka menggunakan 10 primer

\begin{tabular}{|c|c|c|c|c|c|c|c|}
\hline No & Penanda RAPD (bp) & $\begin{array}{c}\text { Bulk Sangat } \\
\text { Toleran }\end{array}$ & Bulk Peka & No & $\begin{array}{c}\text { Penanda RAPD } \\
\text { (bp) }\end{array}$ & $\begin{array}{c}\text { Bulk Sangat } \\
\text { Toleran } \\
\end{array}$ & Bulk Peka \\
\hline 1 & $\mathrm{E}_{1} 300$ & 1 & 1 & 56 & $\mathrm{E}_{19} 750$ & 1 & 1 \\
\hline 2 & $\mathrm{E}_{1} 350$ & 1 & 1 & 57 & $\mathrm{E}_{19} 800$ & 1 & 1 \\
\hline 3 & $\mathrm{E}_{1} 550$ & 1 & 1 & 58 & $\mathrm{E}_{19} 900$ & 1 & 1 \\
\hline 4 & $\mathrm{E}_{1} 750$ & 1 & 1 & 59 & $\mathrm{E}_{19} 1000$ & 1 & 1 \\
\hline 5 & $\mathrm{E}_{1} 800$ & 1 & 1 & 60 & $\mathrm{H}_{2} 300$ & 1 & 1 \\
\hline 6 & $\mathrm{E}_{1} 900$ & 1 & 1 & 61 & $\mathrm{H}_{2} 500$ & 1 & 1 \\
\hline 7 & $\mathrm{E}_{1} 950$ & 1 & 1 & 62 & $\mathrm{H}_{2} 550$ & 1 & 1 \\
\hline 8 & $\mathrm{E}_{1} 1000$ & 1 & 1 & 63 & $\mathrm{H}_{2} 650$ & 0 & 1 \\
\hline 9 & $\mathrm{E}_{1} 1100$ & 1 & 1 & 64 & $\mathrm{H}_{2} 850$ & 1 & 1 \\
\hline 10 & $\mathrm{E}_{1} 1150$ & 1 & 1 & 65 & $\mathrm{H}_{2} 900$ & 1 & 1 \\
\hline 11 & $\mathrm{E}_{1} 1750$ & 1 & 1 & 66 & $\mathrm{H}_{2} 1100$ & 1 & 1 \\
\hline 12 & $\mathrm{E}_{7} 300$ & 0 & 1 & 67 & $\mathrm{H}_{2} 1150$ & 1 & 1 \\
\hline 13 & $\mathrm{E}_{7} 350$ & 1 & 1 & 68 & $\mathrm{H}_{2} 1200$ & 1 & 1 \\
\hline 14 & $\mathrm{E}_{7} 400$ & 1 & 1 & 69 & $\mathrm{H}_{5} 200$ & 1 & 1 \\
\hline 15 & $\mathrm{E}_{7} 450$ & 1 & 1 & 70 & $\mathrm{H}_{5} 300$ & 1 & 1 \\
\hline 16 & $\mathrm{E}_{7} 500$ & 1 & 1 & 71 & $\mathrm{H}_{5} 500$ & 0 & 1 \\
\hline 17 & $\mathrm{E}_{7} 550$ & 1 & 1 & 72 & $\mathrm{H}_{5} 600$ & 1 & 1 \\
\hline 18 & $\mathrm{E}_{7} 600$ & 0 & 1 & 73 & $\mathrm{H}_{5} 650$ & 0 & 1 \\
\hline 19 & $\mathrm{E}_{7} 650$ & 0 & 1 & 74 & $\mathrm{H}_{5} 700$ & 1 & 1 \\
\hline 20 & $\mathrm{E}_{7} 700$ & 1 & 1 & 75 & $\mathrm{H}_{5} 1100$ & 0 & 1 \\
\hline 21 & $\mathrm{E}_{7} 800$ & 0 & 1 & 76 & $\mathrm{H}_{13} 200$ & 1 & 1 \\
\hline 22 & $\mathrm{E}_{7} 850$ & 0 & 1 & 77 & $\mathrm{H}_{13} 350$ & 1 & 1 \\
\hline 23 & $\mathrm{E}_{7} 900$ & 1 & 1 & 78 & $\mathrm{H}_{13} 450$ & 1 & 1 \\
\hline 24 & $\mathrm{E}_{7} 950$ & 1 & 1 & 79 & $\mathrm{H}_{13} 550$ & 1 & 1 \\
\hline 25 & $\mathrm{E}_{7} 1000$ & 1 & 1 & 80 & $\mathrm{H}_{13} 600$ & 1 & 1 \\
\hline 26 & $\mathrm{E}_{7} 1100$ & 1 & 1 & 81 & $\mathrm{H}_{13} 750$ & 1 & 1 \\
\hline 27 & $\mathrm{E}_{7} 1150$ & 0 & 1 & 82 & $\mathrm{H}_{13} 900$ & 1 & 1 \\
\hline 28 & $\mathrm{E}_{7} 1200$ & 0 & 1 & 83 & $\mathrm{H}_{13} 1400$ & 1 & 1 \\
\hline 29 & $\mathrm{E}_{7} 1250$ & 0 & 1 & 84 & $\mathrm{H}_{16} 200$ & 1 & 1 \\
\hline 30 & $\mathrm{E}_{7} 1300$ & 0 & 1 & 85 & $\mathrm{H}_{16} 350$ & 1 & 1 \\
\hline 31 & $\mathrm{E}_{7} 1350$ & 0 & 1 & 86 & $\mathrm{H}_{16} 450$ & 1 & 1 \\
\hline 32 & $\mathrm{E}_{7} 1400$ & 0 & 1 & 87 & $\mathrm{H}_{16} 550$ & 1 & 1 \\
\hline 33 & $\mathrm{E}_{7} 1450$ & 0 & 1 & 88 & $\mathrm{H}_{16} 800$ & 1 & 1 \\
\hline 34 & $\mathrm{E}_{7} 1500$ & 0 & 1 & 89 & $\mathrm{H}_{16} 1000$ & 1 & 1 \\
\hline 35 & $\mathrm{E}_{7} 1600$ & 0 & 1 & 90 & $\mathrm{H}_{16} 1100$ & 1 & 1 \\
\hline 36 & $\mathrm{E}_{7} 1700$ & 0 & 1 & 91 & $\mathrm{H}_{16} 1300$ & 1 & 1 \\
\hline 37 & $E_{10} 300$ & 1 & 1 & 92 & $\mathrm{H}_{16} 1500$ & 1 & 1 \\
\hline 38 & $\mathrm{E}_{10} 350$ & 1 & 1 & 93 & $\mathrm{H}_{16} 1600$ & 1 & 1 \\
\hline 39 & $\mathrm{E}_{10} 500$ & 1 & 1 & 94 & $\mathrm{H}_{19} 400$ & 1 & 1 \\
\hline 40 & $\mathrm{E}_{10} 550$ & 1 & 1 & 95 & $\mathrm{H}_{19} 500$ & 1 & 1 \\
\hline 41 & $\mathrm{E}_{10} 650$ & 1 & 1 & 96 & $\mathrm{H}_{19} 900$ & 1 & 1 \\
\hline 42 & $\mathrm{E}_{10} 700$ & 1 & 1 & 97 & $\mathrm{H}_{19} 950$ & 1 & 1 \\
\hline 43 & $\mathrm{E}_{10} 800$ & 1 & 1 & 98 & $\mathrm{H}_{19} 1000$ & 1 & 1 \\
\hline 44 & $\mathrm{E}_{10} 850$ & 1 & 1 & 99 & $\mathrm{H}_{19} 1100$ & 1 & 1 \\
\hline 45 & $\mathrm{E}_{10} 1000$ & 1 & 1 & 100 & $\mathrm{H}_{19} 1200$ & 1 & 1 \\
\hline 46 & $\mathrm{E}_{10} 1100$ & 1 & 1 & 101 & $\mathrm{H}_{19} 1400$ & 1 & 1 \\
\hline 47 & $\mathrm{E}_{10} 1500$ & 1 & 1 & 102 & $M_{18} 600$ & 1 & 1 \\
\hline 48 & $\mathrm{E}_{10} 1700$ & 1 & 1 & 103 & $\mathrm{M}_{18} 700$ & 1 & 1 \\
\hline 49 & $\mathrm{E}_{10} 1900$ & 1 & 1 & 104 & $\mathrm{M}_{18} 800$ & 1 & 1 \\
\hline 50 & $\mathrm{E}_{10} 2000$ & 1 & 1 & 105 & $\mathrm{M}_{18} 1100$ & 1 & 1 \\
\hline 51 & $\mathrm{E}_{19} 200$ & 1 & 1 & 106 & $\mathrm{M}_{18} 1200$ & 1 & 1 \\
\hline 52 & $\mathrm{E}_{19} 400$ & 1 & 1 & 107 & $\mathrm{M}_{18} 1300$ & 1 & 1 \\
\hline 53 & $\mathrm{E}_{19} 450$ & 1 & 1 & 108 & $\mathrm{M}_{18} 1400$ & 1 & 1 \\
\hline 54 & $\mathrm{E}_{19} 500$ & 1 & 1 & 109 & $\mathrm{M}_{18} 1900$ & 1 & 1 \\
\hline 55 & $\mathrm{E}_{19} 650$ & 1 & 1 & & & & \\
\hline Jumlah & & 40 & 55 & & & 50 & 54 \\
\hline Total & & & & & & 90 & 109 \\
\hline
\end{tabular}

Keterangan: $\mathrm{bp}=$ pasang basa, $0=$ tidak ada pita, $1=$ ada pita 
dalam jumlah banyak. DNA kemudian dielektroforesis dan divisualisasi dengan sinar ultraviolet (Pratiwi, 2001). Pita DNA yang muncul pada hasil visualisasi diamati.

Hasil visualisasi yang menunjukkan bahwa pita DNA dari primer dan panjang basa yang sama muncul di seluruh kelas toleransi, berarti primer tersebut tidak polimorfik terhadap bulk sangat toleran (Gambar 7). Artinya, urutan basa pada primer tersebut tidak berpasangan dengan gen toleran layu bakteri, melainkan gen lain yang umum ada pada tanaman tomat. Primer disebut polimorfik apabila memunculkan pita DNA spesifik pada bulk sangat toleran namun tidak memunculkan pita DNA pada bulk kelas toleransi lainnya.

\section{KESIMPULAN}

Dari 37 genotipe tomat yang diuji terdapat 6 genotipe yang tergolong sangat toleran yaitu tomat varietas Mutiara dan Opal dari Balitsa, tomat lokal Cung dan Syu dari Bengkulu, tomat Lokal Kudamati I dari Ambon, dan Tomat lokal Kefaminano XIV dari Nusa Tenggara Timur. Tidak ditemukan primer RAPD operon $\mathrm{F}$ yang dapat mendeteksi gen penyandi sifat toleran terhadap layu bakteri $R$. solanacearum.

\section{DAFTAR PUSTAKA}

Adhitya, T., R. Rogomulyo, dan S. Waluyo. Pengaruh tingkat naungan dan dosis pupuk urea terhadap pertumbuhan dan hasil sambiloto (Andrographis paniculata Nees.). Fakultas Pertanian Universitas Gajah Mada. Yogyakarta.

BPS. 2012. Statistik pertanian hortikultura. Produksi sayuran di Indonesia. Badan Pusat Statistik Republik Indonesia. Jakarta.
Direktorat Perlindungan Hortikultura. 2012. OPT Tanaman sayuran. Layu bakteri. Kementrian Pertanian Direktorat Jenderal Hortikultura. Jakarta.

Dumeke, T. dan R.P. Adam. 1994. The use of PCR-RAPD analysis plant taxonomy and evolution. p. 179-191. In Griffin, H.G, and A.M. Griffin (Eds.). PCR Technology Current Innovations. CRC Press. Inc. London.

European and Mediteranian Plant Production Organization. 2004. Diagnostic protocols for regulated pests: Ralstonia solanacearum. EPPO Bulletin 34: 173-178.

Hartman, G.L. and J.G. Elphinstone. 1994. Advances in the control of Pseudomonas solanacearum race 1 in major food crops. Di dalam: Hayward A.C., dan G.J. Hartman. (Eds.) Bacterial wilt. The disease and its causative agent, Pseudomonas solanacearum. Wallingford $\mathrm{CAB}$ International:157-177.

Herison, C., S. Winarsih, M. Handayaningsih, dan Rustikawati. 2012. DNA marker assisted and morphological selection on $\mathrm{BC} 3$ genotypes shortcut the introgression of CMV tolerance genes on chili pepper. Agrivita 35: 215-224.

Klein-Lankhorst, R. M, A. Vermunt, R. Weide, T. Liharska, and P. Zabel. 1991. Isolation of molecular markers for tomato ( $L$. esculentum) using random amplified polymorphic DNA (RAPD). Theor Appl Genet 83:108114.

Martin, C. dan E.R. French. 1985 Bacterial Wilt of Potato Ralstonia solanacea- 
rum. Technical Information Bulletin (13) : 1-8.

Mew, T.W., and W.C. Ho. 1977. Effect of soil temperature on resistance of omato cultivars to bacterial wilt. Phytopathology 67:909-911.

Monma, S. dan Y. Sakata. 1993. Inheritance of resistance to Bacterial Wilt in Tomato. Bacterial Wilt Proceedings of International Symposium Kaohsiung, Taiwan 28-31 Oktober 1992. Prosiding ACIAR (45) : 149153

Nurhayati, A., Mazid, dan Y. Serliana. 2011. Pengaruh umur tanaman dan dosis pupuk kalium terhadap infeksi penyakit bulai. Majalah Ilmiah Sriwijaya XIX (12): 682-686.

Pratiwi, R. 2001. Mengenal metode elektroforesis. Oseana XXVI (1): 25-31.

Purwati, E. 2008. Hubungan antara karakteristik fenotipik buah tomat dengan jumlah biji. J. Agrivivor 7(3): 222-229.

Purwati, E., B.A. H.P. Jaya, dan S. Sahat. 2001. Tiga varietas unggul baru tomat dataran rendah. J. Hortikultura 11(1): 71-75.

Rostiana, T., S.F. Chaidamsari, Syahid, W. Hayudin, dan S. Aisyah. 2010. Isolasi dan karakterisasi gen penyandi sifat tahan terhadap bakteri layu pada jahe. Laporan Teknis Penelitian Balai Penelitian Tanaman Obat dan Aromatik. Bogor.

Sastra, D.R. 2013. Masa inkubasi bakteri patogenik Ralstonia solanacearum ras 3 pada beberapa klon kentang. J. Agronomi 8(1): 63-67.
Scott, J.W., G.C. Somodi, dan J.B. Jones. 1993. Testing tomato genotypes and breeding for resistance to bacterial wilt in Florida. Dalam Hartman, G.L. dan A.C. Haywood (eds.). Bacterial Wilt Proceedings of International Symposium Kaohsiung, Taiwan 2831 Oktober 1992. Prosiding ACIAR (45) : 126-131.

Siagian, A. 2005. Lycopene : senyawa fitokimia pada tomat dan semangka. USU e-Journal 9(2).

Stansburry, C., S. McKirdy, A. Mackie, dan G. Power. 2001. Bacterial wilt Ralstonia solanacearum-race 3 Exotic threat to Western Australia. Fact Sheet e-Journal (7) http://www.agric. wa.gov.au/objtwr/imported_assets/ content/pw/ph/dis/veg/fs00701.pdf Diakses 30 Januari 2014.

Sumenda, L., H.L. Ramped and F.R. Mantiri. 2011. Analisis kandungan klorofil daun mangga (Mangifera indica L.) pada tingkat perkembangan daun yang berbeda. J. Bioslogos 1(1): 2024

Tiwari, J.K., N. Mehta, M.K. Singh, and P.S. Tiwari. 2012. Screening of tomato genotypes against bacterial wilt (Ralstonia solanacearum) under field condition for Chhattisgarh. Global Journal of Bio-science and Biotechnology 1(2): 168-170.

USDA-NRI. 2009. Bacterial wilt of tomato. $R$. solanacearum race 3 biovar 2: detection, exclusion and analysis of a select agent educational modules. $11 \mathrm{p}$.

Waldron, J., C.P. Peace, I.R. Searle, A. Furtado, N. Wade, I. Findlay, M.W. Graham, and B.J. Carroll. 2002. 
Randomly amplified DNA fingerprinting: A culmination of DNA marker technologies based on arbitrarily-primed PCR amplification. J. Biomed Biotechnol 2(3): 141-150.

Wechter, W.P., M.P. Whitehead, C.E. Thomas, and R.A. Dean. 1995. Identification of randomly amplified polymorphic DNA marker linked to the Fom 2 Fusarium wilt resistance gene in muskmelon MR-1. The American Phytopathological Society: 12451249.
Williams, J. G. K., A. R. Kubelik, K. J. Livak, J. A. Ravalski, and S.V. Tingey. 1990. DNA polymorphisms amplified by arbitrary primers are usefull as genetic markers. Nucleic Acid Research 18(22): 6531-6535.

Winstead, N. N. dan A. Kelman. 1952. Inoculation techniques for evaluating resistance to Pseudomonas solanacearum. Phytopathology 42: 628-634. 